\title{
Discussion: Empirical correlations for the compression index of Irish soft soils
}

\section{Bryan A. McCabe}

College of Engineering and Informatics, National University of Ireland, Galway, Ireland

\section{Brian B. Sheil}

College of Engineering and Informatics, National University of Ireland, Galway, Ireland

Michael M. Long

School of Civil, Structural and Environmental Engineering, University College, Dublin, Ireland

\section{Fintan J. Buggy}

Roughan O'Donovan Consulting Engineers, Sandyford, Dublin, Ireland Eric R. Farrell

AGL Consulting Geotechnical Engineers, Sandyford, Dublin, Ireland

Paul Quigley BE CEng MIEI

Gavin and Doherty Geosolutions, Dublin, Ireland

\section{Contribution by P. Quigley}

McCabe et al. (2014) have presented some very useful correlations between index properties and compression indices $\left(C_{\mathrm{c}}\right)$ from a wide range of sites across Ireland. Most of the specimens appear to have been obtained from lacustrine or estuarine deposits in Ireland. The paper contains a single data point for marl which does not fit well with the correlations proposed by the authors. Some additional data for marl and other Irish soils are presented below.

Marl (or calcareous silt) is encountered on many road schemes across the limestone regions in Ireland and can result in significant settlements when loaded. Marl was typically formed by calcium-rich water seeping upwards from the underlying limestone through lake muds into a lake basin (Long and Rodgers, 1995). Marl frequently contains a large number of shells that were deposited at the base of the lake. Index tests commonly show that the natural water content is greater than the liquid limit due to the breakdown of the soil structure during the liquid limit test.

Natural water contents and corresponding compression indices from a number of sites in Ireland are presented in Table 4 and plotted in Figure 8. The samples were taken with a 100 or $101 \mathrm{~mm}$ diameter piston sampler with $30^{\circ}$ cutting edges. In addition to the marl sites, a site from the Foyle Valley in Northern Ireland is included. Quigley et al. (2014) describe how there is some evidence to suggest that these silts are structured, which is uncommon in Ireland. Some additional data on silts with high water contents underlying the marl from Hunt (1991), McGill (1990) and Naughton (1996) are included for completeness. Figure 8 shows that the scatter in $C_{\mathrm{c}}$ values at higher water contents is more pronounced and care should be exercised in using empirical relationships. There is reasonable agreement between the relationship between natural water content and $C_{\mathrm{c}}$ proposed by the authors for the high water content organic silt reported by Hunt (1991). However, the relationship typically overpredicts $C_{\mathrm{c}}$ for marl. A revised correlation between the natural water content $\left(w_{\mathrm{n}}\right)$ and the compression index for marl, which may be more applicable, is shown on Figure 8. The geological origin of the additional data differs from the origins of the majority of the data examined by the authors. The relationship between natural water content and compression index proposed by the authors would appear to be valid for natural water contents up to about $110 \%$, but may lead to conservative estimates at higher water contents, which are typical of marl at many sites in Ireland. As suggested by the authors in the original paper, consolidation tests on Class 1 samples should be carried out to validate any assumption on compressibility, especially at high natural water contents.

\section{Authors' reply}

The authors welcome the additional data on the relationship between $w_{\mathrm{n}}$ and $C_{\mathrm{c}}$ for marl and other types of Irish soils and the proposed revised correlation for marl. The additional data include results from a structured silt from the Foyle Valley, which is described in the paper by Quigley et al. (2014). The marl and the structured silt both have liquidity indices significantly greater than unity, which is indicative of a sensitive soil. It is noted by Quigley et al. (2014) that $C_{\mathrm{c}}$ on the Foyle Valley data was best related to the $w_{\mathrm{n}}$ rather than $w_{\mathrm{L}}$, which is consistent with the findings of McCabe et al. (2014). The correlation given in the paper by McCabe et al. (2014) was limited to $w_{\mathrm{n}}<150 \%$ as there was much more scatter and decreasing reliability in the extrapolation of the original correlation at high moisture contents. The $r^{2}$ value is not given for the correlation equation on the contributor's Figure 8; however, it is estimated to be about $0 \cdot 65$, which is considerably less than the value of 0.86 for the data series selected by McCabe et al. (2014). Some of the scatter may be related to the organic content; however, this requires further research. 


\begin{tabular}{|c|c|c|c|c|}
\hline Reference & Site location & Soil type & Natural water content: \% & $C_{c}$ \\
\hline \multirow[t]{2}{*}{ Fahy (1990) } & Bloomhill, Co Offaly & Marl & $183 \cdot 0$ & $1 \cdot 771$ \\
\hline & & & $175 \cdot 0$ & $2 \cdot 527$ \\
\hline \multirow[t]{13}{*}{ Hunt (1991) } & Terryland, Galway & Marl & $288 \cdot 5$ & 3.086 \\
\hline & & & $254 \cdot 0$ & $3 \cdot 190$ \\
\hline & & & $294 \cdot 7$ & $2 \cdot 700$ \\
\hline & & & $232 \cdot 9$ & $2 \cdot 287$ \\
\hline & & & $182 \cdot 9$ & $2 \cdot 355$ \\
\hline & & & $251 \cdot 7$ & $3 \cdot 947$ \\
\hline & & & $234 \cdot 3$ & $2 \cdot 214$ \\
\hline & & & $186 \cdot 0$ & 1.764 \\
\hline & & & $220 \cdot 0$ & $2 \cdot 276$ \\
\hline & & & $207 \cdot 5$ & $2 \cdot 056$ \\
\hline & & & $191 \cdot 5$ & 1.891 \\
\hline & & & $202 \cdot 2$ & 2.094 \\
\hline & & & $166 \cdot 3$ & 1.486 \\
\hline \multirow[t]{9}{*}{ Hunt (1991) } & Terryland, Galway & Silt & $166 \cdot 3$ & 1.419 \\
\hline & & & 264.9 & $3 \cdot 244$ \\
\hline & & & $216 \cdot 6$ & $2 \cdot 337$ \\
\hline & & & $220 \cdot 4$ & $2 \cdot 807$ \\
\hline & & & $181 \cdot 3$ & $2 \cdot 167$ \\
\hline & & & $215 \cdot 3$ & $3 \cdot 012$ \\
\hline & & & $216 \cdot 5$ & $2 \cdot 603$ \\
\hline & & & $215 \cdot 3$ & 4.023 \\
\hline & & & $164 \cdot 9$ & $2 \cdot 262$ \\
\hline \multirow[t]{6}{*}{ Naughton (1996) } & Ballinfoyle, Galway & Marl & $150 \cdot 4$ & $1 \cdot 442$ \\
\hline & & & $137 \cdot 0$ & $1 \cdot 506$ \\
\hline & & & $143 \cdot 9$ & $1 \cdot 284$ \\
\hline & & & $150 \cdot 4$ & 1.578 \\
\hline & & & $145 \cdot 2$ & $1 \cdot 300$ \\
\hline & & & $142 \cdot 2$ & $1 \cdot 349$ \\
\hline McGill (1990) & Wilton, Co Cork & Marl & $191 \cdot 0$ & $2 \cdot 550$ \\
\hline \multirow[t]{8}{*}{ McGill (1990) } & Wilton, Co Cork & Silt & $98 \cdot 0$ & 1.092 \\
\hline & & & $47 \cdot 0$ & 0.434 \\
\hline & & & $81 \cdot 1$ & $2 \cdot 545$ \\
\hline & & & $41 \cdot 0$ & 0.755 \\
\hline & & & $68 \cdot 6$ & 0.304 \\
\hline & & & $78 \cdot 7$ & 0.546 \\
\hline & & & $57 \cdot 9$ & 0.789 \\
\hline & & & $46 \cdot 8$ & 0.757 \\
\hline \multirow[t]{7}{*}{ Quigley et al. (2014) } & Foyle Valley & Silt & $99 \cdot 5$ & 1.070 \\
\hline & & & $109 \cdot 0$ & 1.062 \\
\hline & & & $114 \cdot 8$ & $1 \cdot 244$ \\
\hline & & & $110 \cdot 0$ & $1 \cdot 413$ \\
\hline & & & $106 \cdot 9$ & $1 \cdot 146$ \\
\hline & & & $106 \cdot 2$ & 1.408 \\
\hline & & & $108 \cdot 1$ & $1 \cdot 146$ \\
\hline \multirow[t]{2}{*}{ Unpublished } & Athlone & Marl & $131 \cdot 0$ & $1 \cdot 220$ \\
\hline & & & $150 \cdot 0$ & 1.420 \\
\hline Unpublished & Terryland, Galway & Marl & $173 \cdot 0$ & $3 \cdot 021$ \\
\hline Unpublished & Tuam & Marl & $173 \cdot 0$ & 1.460 \\
\hline
\end{tabular}

Table 4. Natural water content and compression index data 


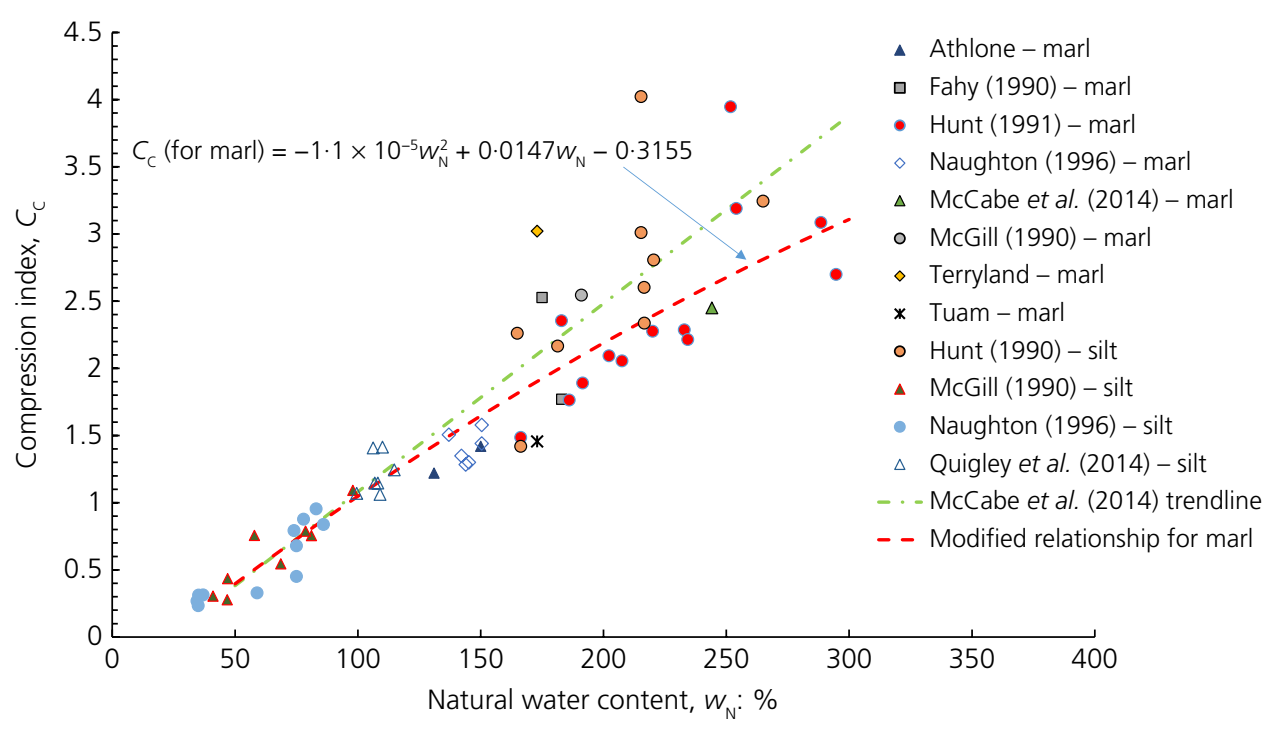

Figure 8. Relationship between natural water content and compression index

\section{REFERENCES}

Fahy P (1990) Geotechnical Investigation of Peat Stockpile Loading on Soft Soil Deposits. MEngSc thesis, National University of Ireland, Galway, Ireland. Hunt P (1991) Analysis of Soft Soil Deposits at a Location on the Eastern Approach Road, Galway. MEngSc thesis, National University of Ireland, Galway, Ireland. Long M and Rodgers M (1995) Geotechnical behaviour of very soft calcareous soils in Ireland. Proceedings of the 11th European Conference on Soil Mechanics and Foundation Engineering, Copenhagen, Denmark, vol. 8, pp. 103-108.

McCabe BA, Sheil BB, Long MM, Buggy FJ and Farrell ER (2014) Empirical correlations for the compression index of Irish soft soils. Proceedings of the Institution of Civil
Engineers - Geotechnical Engineering 167(6): 510-517, http://dx.doi.org/10.1680/geng.13.00116.

McGill E (1990) Geotechnical Data Base Information Base and Analysis System for Soft Soils. MEngSc thesis, National University of Ireland, Galway, Ireland.

Naughton P (1996) An Examination of the Use of Timber Piles for the Construction of Embankments on Soft Compressible Soils. MEngSc thesis, National University of Ireland, Galway, Ireland.

Quigley P, Long M, Solera S, Raynor D and Ruta C (2014) Some geotechnical characteristics of a soft soil deposit along the Foyle Valley. In Proceedings of Civil Engineering Research in Ireland (CERI 2014) (Nanukuttan S and Goggins J (eds)). Queens University Belfast, Belfast, Ireland, pp. 415-420. 